\title{
KOMUNIKASI INFORMAL, GAJI, DAN MOTIVASI KERJA KARYAWAN DI PT INDONUSA ALGAEMAS PRIMA BALI
}

\author{
Cynthia Febriana ${ }^{1 *}$, Eddy M. Sutanto ${ }^{1}$ \\ ${ }^{1}$ Program Studi Manajemen, Universitas Kristen Petra \\ Jalan Siwalankerto 121-131, Surabaya 60236, Indonesia \\ *Penulis Korespondensi; Email: cynthia_09092@yahoo.com
}

\begin{abstract}
Abstrak
Penelitian ini bertujuan untuk menguji pengaruh komunikasi informal dan gaji terhadap motivasi kerja karyawan di PT Indonusa Algaemas Prima Bali. Populasi dalam penelitian ini berjumlah 84 orang karyawan lapangan tetap. Sampel penelitian ini menggunakan metode sampel jenuh dengan pendekatan kuantitatif. Metode analisis data yang digunakan adalah regresi linier berganda. Hasil penelitian menunjukkan bahwa komunikasi informal dan gaji berpengaruh positif dan signifikan terhadap motivasi kerja karyawan PT Indonusa Algaemas Prima Bali secara parsial maupun simultan.
\end{abstract}

Kata kunci: Komunikasi informal, gaji, motivasi kerja

\begin{abstract}
The aim of this research was to test whether informal communication and salary affected employee's work motivation in PT Indonusa Algaemas Prima Bali. The population and samples of this research were 84 employees as this research used saturated method sampling with a quantitative approach using a multiple linear regression analysis. The results indicated that informal communication and salary had a positive and significant impact to employee's work motivation in PT Indonusa Algaemas Prima Bali both partially and simultaneously.
\end{abstract}

Keywords: Informal communication, salary, work motivation

\section{Pendahuluan}

Komunikasi formal dan informal yang baik akan memberikan motivasi kepada para karyawan agar mau bekerja keras dan antusias mencapai produktivitas kerja yang tinggi (Putra, 2013). Penelitian Wahyuningsih, Binarsih, dan Istiatin (2012) juga menunjukkan bahwa komunikasi berpengaruh positif dan signifikan terhadap motivasi kerja karyawan.

Menyadari peran karyawan yang sangat penting, maka insentif menjadi hal utama bagi karyawan. Pemberian insentif yang memadai berdampak baik pada pelaksanaan tugas yang maksimal. Insentif merupakan bentuk dari pemberian gaji, upah, dan penghargaan yang diberikan terkait kontribusi mereka dalam perusahaan. Ketidakpuasan dalam penerimaan gaji tentu berdampak pada motivasi rendah dan timbul protes serta turnover dan absensi yang meningkat.

Penelitian ini ditujukan untuk mengetahui bagaimana pengaruh dari komunikasi informal dan gaji terhadap motivasi kerja karyawan di PT Indonusa Algaemas Prima Bali. Bagi karyawan perusahaan, gaji yang diterima bisa saja mempunyai makna yang ber- beda antara karyawan satu dengan lainnya. Perbedaan yang dirasakan itulah yang membentuk motivasi kerja menjadi tinggi atau rendah.

\section{Komunikasi Informal}

Komunikasi merupakan proses penyampaian informasi dari sumber kepada penerima untuk dimengerti, dan dapat merubah tingkah laku penerima seperti yang diinginkan sumber. Kreitner dan Kinicki (2005, p. 198) mendefinisikan komunikasi sebagai pertukaran informasi antara pengirim dan penerima, dan kesimpulan (persepsi) makna antara individu-individu yang terlibat. Secara umum, jaringan komunikasi dibedakan atas jaringan komunikasi formal dan jaringan komunikasi informal. Jaringan komunikasi formal salurannya ditentukan oleh struktur yang telah direncanakan dan harus sesuai. Komunikasi formal mencakup susunan tingkah laku organisasi, pembagian departemen, dan posisi jabatan. Jaringan komunikasi informal tidak direncanakan dan tidak mengikuti struktur organisasi. Komunikasi informal bisa berupa berita dari mulut ke mulut. Menurut Disposoedarmo (2008) pengukuran secara operasional 
untuk komunikasi informal menggunakan indikator tingkat kejelasan pemberian informasi, frekuensi penyampaian informasi, kualitas informasi, kelengkapan sarana komunikasi yang digunakan.

\section{Gaji}

Menurut Mangkunegara (2007), gaji yang diberikan kepada karyawan sangat berpengaruh pada tingkat kepuasan kerja dan motivasi kerja serta hasil kerja karyawan. Ertanto dan Suharnomo (2011) menyatakan ada dua macam pengukuran untuk gaji. Pertama yaitu keadilan internal yang meliputi keadilan internal gaji, keadilan internal tunjangan, keadilan internal insentif, keadilan internal kenaikan gaji. Kedua yaitu keadilan eksternal yang meliputi keadilan eksternal gaji, keadilan eksternal kenaikan tunjangan, keadilan eksternal insentif, dan keadilan eksternal kenaikan gaji.

\section{Motivasi Kerja}

Motivasi adalah hal pokok yang mendorong seseorang untuk bekerja. Manfaat motivasi yang utama adalah menciptakan gairah kerja sehingga produktivitas kerja meningkat. Ciri-ciri orang termotivasi yaitu bekerja sesuai standar, merasa berharga, dan semangat juangnya tinggi (Arep \& Tanjung, 2005). Menurut Malthis (2006), motivasi adalah keinginan dalam diri seseorang yang menyebabkan orang tersebut bertindak. Maslow menjelaskan bahwa kebutuhan adalah kekurangan yang dirasakan seseorang pada saat tertentu yang menimbulkan tegangan yang menyebabkan keinginan (dalam Winarni \& Utomo, 2013).

Menurut George dan Jones (2005) unsur motivasi kerja terbagi menjadi tiga bagian (dalam Adiwinata \& Sutanto, 2014). Hal ini juga menjadi ukuran untuk motivasi kerja karyawan dalam perusahaan. Arah perilaku menjadi hal utama bagi perusahaan yang diukur melalui bagaimana karyawan mempunyai hubungan relasi yang baik dengan rekan kerja dan ketaatan terhadap peraturan kerja dalam perusahaan. Tingkat usaha menjadi indikator kedua bagi perusahaan yang diukur melalui tingkat keefektifan dalam bekerja, tingkat efisiensi dalam bekerja, tingkat keseriusan dalam bekerja dan tingkat keterampilan dalam bekerja. Tingkat kegigihan menjadi poin terakhir bagi perusahaan yang diukur melalui bagaimana karyawan memiliki inisiatif dalam menyelesaikan masalah, konsistensi dalam bekerja, dan pantang menyerah serta tidak mudah putus asa saat ada teguran dari sekitarnya.

\section{Model Penelitian}

Model penelitian dan hubungan antar konsep dimana variabel $X$ (komunikasi informal dan gaji) mempengaruhi variabel $Y$ (motivasi kerja karyawan) digambarkan seperti dalam Gambar 1.

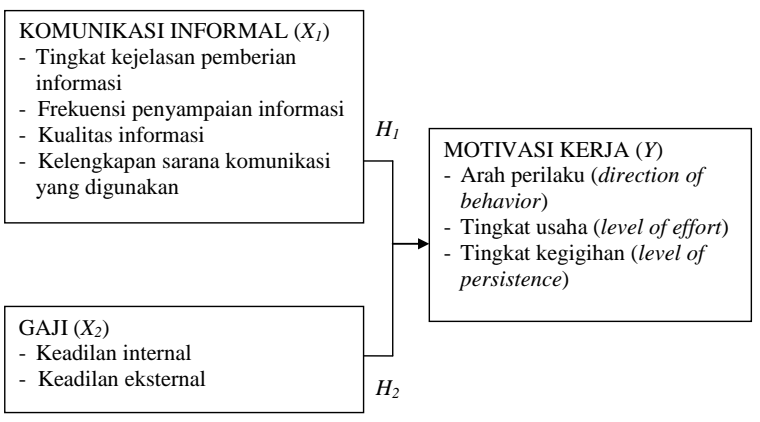

Gambar 1. Model penelitian

Sumber: Disposoedarmo (2008), Ertanto dan Suharnomo (2011), George dan Jones (2005)

Mengacu pada hasil penelitian Putra (2013), Wahyuningsih et al. (2012), Winarni dan Utomo (2013), dan Nugraha, Astuti, dan Hakam (2013) yang menunjukkan bahwa variabel komunikasi informal dan gaji berpengaruh positif dan signifikan pada motivasi kerja, maka hipotesis dalam penelitian ini antara lain:

$H_{1}$ : Komunikasi informal berpengaruh positif pada motivasi kerja karyawan di PT Indonusa Algaemas Prima Bali.

$\mathrm{H}_{2}$ : Gaji berpengaruh positif pada motivasi kerja karyawan di PT Indonusa Algaemas Prima Bali.

\section{Metode Penelitian}

Metode penelitian menggunakan metode kuantitatif, yaitu metode penelitian terhadap sampel tertentu dan pengumpulan datanya menggunakan instrumen penelitian serta analisis datanya bersifat kuantitatif/ statistik dengan tujuan menguji hipotesa yang telah ditetapkan (Sugiyono, 2010). Penelitian ini merupakan penelitian penjelasan (explanatory research) yang akan membuktikan hubungan kausal antara variabel independen yaitu komunikasi informal dan gaji terhadap variabel dependen yaitu motivasi kerja.

Populasi dalam penelitian ini adalah seluruh karyawan lapangan tetap di PT Indonusa Algaemas Prima Bali. Berdasarkan data perusahaan jumlah karyawan lapangan tetap sebanyak 84 orang. Teknik pengambilan sampel yang digunakan adalah sampel jenuh (sensus) yang jumlahnya sama dengan jumlah populasi. 


\section{Prosedur Pengumpulan Data}

Metode pengumpulan data dalam penelitian ini melalui angket penelitian. Menurut Sugiyono (2010) angket penelitian merupakan teknik pengumpulan data yang dilakukan dengan cara memberi seperangkat pernyataan tertulis kepada responden untuk dijawabnya. Metode ini dilakukan dengan membagikan angket penelitian kepada sampel. Penelitian ini menggunakan skala likert untuk memperoleh data interval dengan lima kategori (Cooper \& Schindler, 2008).

\section{Metode Analisis Data}

Metode analisis data dalam penelitian ini menggunakan uji validitas, uji reliabilitas, uji asumsi klasik, analisis statistik deskriptif, dan analisis regresi linier berganda dengn menggunakan SPSS for Windows Ver. 16.0. Uji validitas digunakan untuk mengungkapkan sesuatu yang diukur oleh angket penelitian. Uji reliabilitas digunakan untuk mengukur konsistensi jawaban responden dari waktu ke waktu.

Uji asumsi klasik dilakukan dengan empat pengujian, yaitu uji normalitas yang bertujuan untuk menguji apakah variabel dependen dan variabel independen mempunyai distribusi normal atau tidak, uji multikolinieritas ditujukan untuk menunjukkan adanya hubungan linier sempurna antara variabel bebas dalam model regresi, uji heteroskedastisitas untuk menunjukkan adanya ketidaksamaan varian residual atas suatu pengamatan ke pengamatan yang lain, dan uji autokorelasi untuk menguji apakah dalam suatu model regresi ada korelasi antara kesalahan pengganggu pada periode satu dengan kesalahan pada periode sebelumnya.

Analisis statistik deskriptif menggunakan alat ukur mean yang digunakan untuk mengetahui bobot rata-rata jawaban responden terhadap tiap indikator variabel. Analisis regresi linier berganda adalah analisis yang digunakan untuk melihat secara langsung pengaruh beberapa variabel bebas terhadap variabel terikat.

\section{Prosedur Pengujian Hipotesis}

Uji $t$ pada dasarnya menunjukkan seberapa jauh pengaruh satu variabel penjelas secara individual dalam menerangkan variabel-variabel terikat. Uji $F$ pada dasarnya menunjukkan apakah semua variabel bebas yang dimasukkan dalam model mempunyai pengaruh terhadap variabel terikat.

\section{Hasil Penelitian dan Pembahasan}

PT Indonusa Algaemas Prima Bali adalah perusahaan swasta yang bergerak dalam bidang agrobisnis, khususnya industri pengolahan rumput laut.
Perusahaan ini berdiri sejak tahun 1995 dan kini mampu memproduksi rumput laut olahan menjadi Alkali Treated Eucheuma Cottonii Chips (ATC). Pelanggan yang dijangkau oleh perusahaan yaitu di Amerika Serikat, Eropa, dan Asia. Karyawan lapangan tetap dalam perusahaan ini memegang peranan penting dalam proses kerja. Hal ini disebabkan karena mereka lebih tahu situasi dalam lapangan untuk mengantisipasi proses pengolahan rumput laut yang merupakan tahap penting dalam produktivitas perusahaan. Perusahaan ini dijadikan objek penelitian karena adanya komunikasi informal yang jarang digunakan oleh perusahaan besar serta gaji yang kurang sebanding dengan pekerjaan yang dilakukan. Akses yang mudah juga menjadi alasan berikutnya untuk kemudahan mendapat data dari karyawan lapangan tetap perusahaan.

Uji validitas dilakukan untuk mengetahui sejauh mana indikator dalam angket dapat mengukur konsep yang diinginkan. Hasil uji validitas angket penelitian dapat dilihat pada Tabel 1.

Pada Tabel 1 diketahui bahwa semua item pernyataan atau indikator pada setiap variabel penelitian menghasilkan nilai corrected item-total correlation yang lebih besar $r_{\text {tabel }} 0,215$. Dengan demikian dapat dikatakan bahwa indikator yang mengukur setiap variabel dapat dinyatakan valid. Hal ini disebabkan karena karyawan lapangan tetap perusahaan menjawab sesuai dengan ukuran yang diberikan di dalam angket penelitian.

Uji reliabilitas dilakukan untuk mengetahui kehandalan variabel dalam penelitian yang hasilnya seperti terlihat dalam Tabel 2.

Berdasarkan Tabel 2 dapat diketahui bahwa setiap variabel penelitian mempunyai nilai cronbach's alpha yang lebih besar dari nilai kritis 0,6 sehingga dapat disimpulkan bahwa kuesioner dalam penelitian ini telah memenuhi syarat kehandalan angket atau reliabel. Hal ini disebabkan karena karyawan lapangan tetap perusahaan merasakan hal yang sama dan sesuai dengan harapannya.

Pada analisis regresi pengujian normalitas dilakukan pada nilai residual model regresi. Prosedur uji normalitas dilakukan dengan metode grafik yaitu Normal Probability Plot, yang mana setiap titik-titik di dalam grafik diharapkan menyebar di sekitar garis diagonal yang menunjukkan bahwa asumsi normalitas residual model telah terpenuhi. Gambar 2 adalah grafik Normal Probability Plot yang menunjukkan bahwa asumsi normalitas telah terpenuhi.

Multikolinieritas menunjukkan adanya hubungan linier sempurna antara variabel bebas dalam model regresi. Model regresi yang baik tidak boleh mengandung multikolinieritas. Pendeteksian ada atau tidak- 
nya multikolinieritas dilakukan dengan melihat nilai tolerance dan VIF. Apabila nilai tolerance $>0,10$ dan nilai $V I F<10$, maka model regresi bebas dari multikolinieritas. Berikut adalah hasil uji multikolinieritas (Tabel 3).

\section{Tabel 1}

\section{Hasil Uji Validitas}

\begin{tabular}{|c|c|c|c|}
\hline Variabel & Indikator & $\begin{array}{l}\text { Corrected Item- } \\
\text { Total Correlation }\end{array}$ & Keterangan \\
\hline Komunikasi & $X_{1.1}$ Saya merasa pemberian informasi dari karyawan sudah jelas & 0,722 & Valid \\
\hline \multirow{3}{*}{ Informal } & $X_{1.2}$ Frekuensi penyampaian informasi oleh karyawan sudah baik & 0,737 & Valid \\
\hline & $\begin{array}{l}X_{1.3} \\
\begin{array}{l}\text { Kualitas penyampaian membantu saya dalam menjalankan } \\
\text { perintah }\end{array}\end{array}$ & 0,663 & Valid \\
\hline & $\begin{array}{l}X_{1.4} \text { Kelengkapan sarana komunikasi yang digunaan membantu } \\
\text { saya dalam menerima perintah }\end{array}$ & 0,698 & Valid \\
\hline \multirow[t]{8}{*}{$\overline{\text { Gaji }}$} & $\begin{array}{ll}X_{2.1} & \text { Gaji saya adil dibandingkan dengan apa yang diterima rekan } \\
\text { kerja saya dalam perusahaan }\end{array}$ & 0,396 & Valid \\
\hline & $\begin{array}{l}X_{2.2} \text { Tunjangan yang saya terima adil dibandingkan dengan rekan } \\
\text { kerja di dalam perusahaan }\end{array}$ & 0,471 & Valid \\
\hline & $\begin{array}{l}X_{2.3} \text { Saya merasa diberi peluang adil dalam menerima imbalan } \\
\text { insentif dibandingkan rekan kerja di dalam perusahaan }\end{array}$ & 0,336 & Valid \\
\hline & $\begin{array}{l}X_{2.4} \text { Kenaikan gaji saya adalah adil dibandingkan dengan } \\
\text { kenaikan gaji rekan kerja di dalam perusahaan }\end{array}$ & 0,450 & Valid \\
\hline & $\begin{array}{ll}X_{2.5} & \text { Gaji saya adil dibandingkan dengan apa yang diterima } \\
\text { karyawan di perusahaan lain }\end{array}$ & 0,417 & Valid \\
\hline & $\begin{array}{l}X_{2.6} \text { Tunjangan yang saya terima adil dibandingkan dengan } \\
\text { karyawan di perusahaan lain }\end{array}$ & 0,430 & Valid \\
\hline & $\begin{array}{ll}X_{2.7} & \text { Saya merasa diberi peluang adil dalam menerima imbalan } \\
\text { insentif dibandingkan karyawan di perusahaan lain }\end{array}$ & 0,391 & Valid \\
\hline & $\begin{array}{ll}X_{2.8} & \text { Kenaikan gaji saya adalah adil dibandingkan dengan } \\
& \text { kenaikan gaji di perusahaan lain } \\
\end{array}$ & 0,463 & Valid \\
\hline \multirow[t]{9}{*}{ Motivasi Kerja } & $\begin{array}{ll}Y_{1.1} & \begin{array}{l}\text { Saya mempunyai hubungan relasi yang baik dengan rekan } \\
\text { kerja }\end{array}\end{array}$ & 0,646 & Valid \\
\hline & $Y_{1.2}$ Saya taat terhadap peraturan kerja dalam perusahaan & 0,603 & Valid \\
\hline & $\begin{array}{ll}Y_{1.3} & \text { Saya selalu berusaha menyelesaikan pekerjaan sesuai } \\
\text { dengan standard organisasi }\end{array}$ & 0,495 & Valid \\
\hline & $\begin{array}{l}Y_{1.4} \begin{array}{l}\text { Saya selalu berusaha untuk tidak melakukan kesalahan } \\
\text { dalam bekerja }\end{array}\end{array}$ & 0,443 & Valid \\
\hline & $Y_{1.5}$ Saya selalu serius dan berkonsentrasi dalam bekerja & 0,378 & Valid \\
\hline & $Y_{1.6}$ Saya bekerja dengan terampil & 0,662 & Valid \\
\hline & $\begin{array}{l}Y_{1.7} \text { Saya memiliki inisiatif memperbaiki hasil kerja yang kurang } \\
\text { baik }\end{array}$ & 0,653 & Valid \\
\hline & $\begin{array}{l}Y_{1.8} \text { Saya selalu bekerja dengan baik dan teliti, baik pada awal } \\
\text { bekerja maupun jam kerja telah usai }\end{array}$ & 0,517 & Valid \\
\hline & $\begin{array}{l}Y_{1.9} \text { Jika saya memperoleh teguran dari pimpinan, saya tidak } \\
\text { mudah menyerah tetapi semakin termotivasi }\end{array}$ & 0,834 & Valid \\
\hline
\end{tabular}

Tabel 2

Hasil Uji Reliabilitas

\begin{tabular}{lcc}
\hline \multicolumn{1}{c}{ Variabel } & Cronbach's Alpha & Keterangan \\
\hline Komunikasi Informal & 0,864 & reliabel \\
Gaji & 0,728 & reliabel \\
Motivasi Kerja & 0,849 & reliabel \\
\hline
\end{tabular}


Normal P-P Plot Regression Standardized Residual Dependent Variable: Motivasi kerja

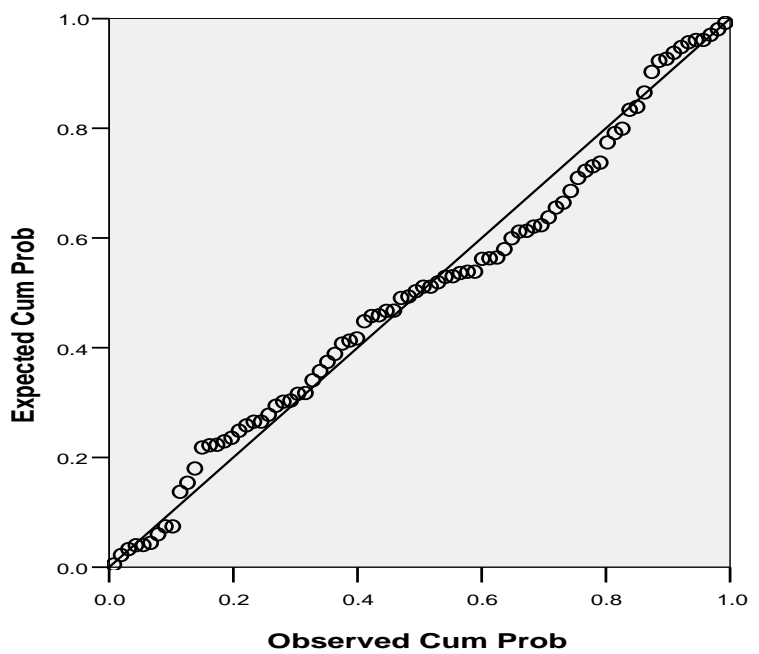

Gambar 2. Grafik normal probability plot

Tabel 3

Hasil Uji Multikolinieritas

\begin{tabular}{lccc}
\hline \multirow{2}{*}{ Variabel } & \multicolumn{2}{c}{ Colinierity Statistics } & \multirow{2}{*}{ Keterangan } \\
\cline { 2 - 3 } & Tolerance & VIF & \\
\hline Komunikasi & 0,833 & 1,200 & Non Multikolinieritas \\
Informal $\left(X_{1}\right)$ & 0,833 & 1,200 & Non Multikolinieritas \\
Gaji $\left(X_{2}\right)$ & & & \\
\hline
\end{tabular}

Berdasarkan Tabel 3 diketahui bahwa nilai tolerance kedua variabel bebas di atas angka 0,10. Demikian pula nilai VIF semuanya di bawah angka 10, sehingga disimpulkan model regresi bebas dari multikolinieritas atau dengan kata lain asumsi non multikolinieritas telah terpenuhi.

Heteroskedastisitas menunjukkan adanya ketidaksamaan varian dari residual atas suatu pengamatan ke pengamatan yang lain. Model regresi yang baik tidak boleh mengandung heteroskedastisitas. Pendeteksian ada atau tidaknya heteroskedastisitas dilakukan dengan menggunakan uji korelasi Rank Spearman, yang mana korelasi ini merupakan hubungan antara variabel bebas model regresi dengan nilai residual yang dihasilkan. Jika signifikansi korelasi yang dihasilkan di atas 0,05, maka dapat disimpulkan bahwa asumsi non heteroskedastisitas model regresi telah terpenuhi. Berikut hasil dari uji Rank Spearman.

Tabel 4

Hasil Uji Heteroskedastisitas

\begin{tabular}{lcc}
\hline Variabel Bebas & $\begin{array}{c}\text { Signifikansi } \\
\text { Rank Spearman }\end{array}$ & Keterangan \\
\hline Komunikasi & 0,493 & Non-Heteroskedastisitas \\
Informal $\left(X_{I}\right)$ & 0,355 & Non-Heteroskedastisitas \\
Gaji $\left(X_{2}\right)$ & & \\
\hline
\end{tabular}

Responden pada penelitian ini adalah seluruh karyawan tetap bagian lapangan dari PT Indonusa Algaemas Prima Bali dengan jumlah responden sebanyak 84 orang. Deskripsi profil responden yang meliputi usia, jenis kelamin, status perkawinan, pendidikan, dan masa kerja dapat dilihat pada Tabel 5.

Tabel 5

Profil Responden

\begin{tabular}{llcc}
\hline & Profil & Frekuensi & Persentase \\
\hline Usia & $<20 \mathrm{Th}$ & 4 & 4,8 \\
& 20-30 Th & 33 & 39,3 \\
& 31-40 Th & 47 & 56,0 \\
\hline Jenis Kelamin & Laki-laki & 27 & 32,1 \\
& Perempuan & 57 & 67,9 \\
\hline Status & Kawin & 67 & 79,8 \\
& Tidak kawin & 17 & 20,2 \\
\hline Pendidikan & SD & 52 & 61,9 \\
& SMP & 20 & 23,8 \\
& SMA & 6 & 7,1 \\
& SMK & 5 & 6,0 \\
& SPG & 1 & 1,2 \\
\hline Lama Bekerja & $<5$ Th & 10 & 11,9 \\
& 5-10 Th & 17 & 20,2 \\
& $11-20$ Th & 57 & 67,9 \\
\hline
\end{tabular}

Berdasarkan Tabel 5 dapat diketahui bahwa mayoritas karyawan dengan usia antara 31-40 tahun sebanyak 47 orang atau $56 \%$ dari total keseluruhan, usia antara di bawah 20 tahun adalah responden dengan jumlah minoritas yaitu sebanyak empat orang $(4,8 \%)$ dari total keseluruhan responden. Dilihat dari segi status perkawinan diketahui bahwa sebagian besar responden memiliki status menikah yaitu sebanyak 67 orang $(79,8 \%)$, sedangkan sisanya yaitu sebanyak 17 orang $(20,2 \%)$ berstatus belum menikah.

Responden dengan status pendidikan terakhir SD adalah responden yang paling banyak menjadi karyawan tetap di bagian lapangan di PT Indonusa Algaemas Prima Bali yaitu sebanyak 52 orang $(61,9 \%)$ dari total keseluruhan responden. Karyawan berpendidikan SPG adalah responden dengan jumlah paling sedikit sebanyak satu orang $(1,2 \%)$ saja.

Dilihat dari masa kerja, dapat diketahui bahwa sebagian besar responden telah bekerja di PT Indonusa Algaemas Prima Bali selama 11-20 tahun, yaitu sebanyak 57 orang $(67,9 \%)$. Responden dengan masa kerja di bawah lima tahun merupakan responden dengan jumlah paling sedikit diantara jumlah responden lainnya, yaitu sebanyak 10 orang (11,9\%).

Analisis deskriptif variabel penelitian dari jawaban responden bertujuan untuk menggambarkan jawaban responden terhadap pernyataan-pernyataan dalam angket penelitian dari masing-masing variabel. Variabel-variabel dalam penelitian ini antara lain komunikasi informal $\left(X_{1}\right)$, gaji $\left(X_{2}\right)$, dan motivasi kerja karyawan $(Y)$. 
Tabel 6

Deskripsi Jawaban Responden mengenai Komunikasi Informal

\begin{tabular}{|c|c|c|}
\hline \multirow[t]{2}{*}{ Indikator } & \multicolumn{2}{|c|}{ Rata- Kategori } \\
\hline & $\begin{array}{lllll}1 & 2 & 3 & 4 & 5 \\
\text { rata }\end{array}$ & \\
\hline $\begin{array}{l}X_{1.1} \text { Saya merasa } \\
\text { pemberian } \\
\text { informasi sudah } \\
\text { jelas }\end{array}$ & $\begin{array}{llllll}0 & 3 & 17 & 46 & 18 & 3,94\end{array}$ & Tinggi \\
\hline $\begin{array}{l}X_{1.2} \text { Frekuensi } \\
\text { penyampaian } \\
\text { informasi oleh } \\
\text { karyawan sudah } \\
\text { baik }\end{array}$ & $\begin{array}{llllll}0 & 0 & 16 & 50 & 18 & 4,02\end{array}$ & Tinggi \\
\hline $\begin{array}{l}X_{1.3} \text { Kualitas } \\
\text { penyampaian } \\
\text { informasi } \\
\text { membantu saya } \\
\text { dalam } \\
\text { menjalankan } \\
\text { perintah }\end{array}$ & $\begin{array}{llllll}0 & 2 & 20 & 41 & 21 & 3,96\end{array}$ & Tinggi \\
\hline $\begin{array}{l}X_{1.4} \text { Kelengkapan } \\
\text { sarana komunikasi } \\
\text { yang digunakan } \\
\text { membantu saya } \\
\text { dalam menerima } \\
\text { perintah } \\
\end{array}$ & $\begin{array}{llllll}0 & 0 & 16 & 48 & 20 & 4,05\end{array}$ & Tinggi \\
\hline Keseluru & 3,99 & Tinggi \\
\hline
\end{tabular}

Berdasarkan Tabel 6 dapat dilihat bahwa persepsi tertinggi mengenai komunikasi informal dirasakan oleh karyawan yaitu pada adanya kelengkapan sarana komunikasi yang digunakan untuk membantu karyawan dalam menerima perintah kerja yaitu dengan nilai rata-rata sebesar 4,05 . Persepsi terendah mengenai komunikasi informal dirasakan oleh karyawan berkaitan dengan kejelasan dalam pemberian informasi kerja yaitu dengan rata-rata sebesar 3,94. Secara keseluruhan diketahui bahwa rata-rata jawaban responden pada indikator variabel komunikasi informal adalah sebesar 3,99 (kategori tinggi dengan interval 3,1-5,0). Ini berarti proses perpindahan informasi dari satu pihak ke pihak lain secara informal di PT Indonusa Algaemas Prima Bali dapat dikatakan berjalan dengan baik.

Berdasarkan Tabel 7 dapat dilihat bahwa persepsi tertinggi mengenai gaji dirasakan oleh karyawan yaitu pada indikator kenaikan gaji yang lebih adil jika dibandingkan dengan kenaikan gaji di perusahaan yang lain, yaitu dengan nilai rata-rata sebesar 3,89. Persepsi terendah mengenai gaji dirasakan oleh karyawan berkaitan dengan keadilan tentang kenaikan gaji jika dibandingkan dengan rekan kerja di dalam perusahaan, yaitu dengan rata-rata sebesar 3,58. Secara keseluruhan diketahui bahwa rata-rata jawaban responden pada indikator variabel gaji adalah se- besar 3,75 yaitu termasuk kategori tinggi. Ini berarti bahwa gaji yang diterima karyawan dapat dikatakan telah sesuai.

Tabel 7

Deskripsi Jawaban Responden mengenai Gaji

\begin{tabular}{|c|c|c|}
\hline \multirow[t]{2}{*}{ Indikator } & Skor & \multirow{2}{*}{$\begin{array}{l}\text { Rata- Kategori } \\
\text { rata }\end{array}$} \\
\hline & $\begin{array}{lllll}1 & 2 & 3 & 4 & 5 \\
\end{array}$ & \\
\hline $\begin{array}{l}X_{2.1} \text { Gaji saya adil } \\
\text { dibandingkan } \\
\text { dengan apa yang } \\
\text { diterima rekan } \\
\text { kerja saya dalam } \\
\text { perusahaan }\end{array}$ & $\begin{array}{lllll}0 & 2 & 42 & 26 & 14\end{array}$ & 3,62 Tinggi \\
\hline $\begin{array}{l}X_{2.2} \text { Tunjangan yang } \\
\text { saya terima adil } \\
\text { dibandingkan } \\
\text { dengan rekan kerja } \\
\text { di dalam } \\
\text { perusahaan } \\
\end{array}$ & $\begin{array}{lllll}0 & 3 & 31 & 36 & 14\end{array}$ & 3,73 Tinggi \\
\hline $\begin{array}{l}X_{2.3} \text { Saya merasa diberi } \\
\text { peluang adil dalam } \\
\text { menerima imbalan } \\
\text { insentif } \\
\text { dibandingkan } \\
\text { rekan kerja di } \\
\text { dalam perusahaan }\end{array}$ & $\begin{array}{lllll}0 & 1 & 36 & 36 & 11\end{array}$ & 3,68 Tinggi \\
\hline $\begin{array}{l}X_{2.4} \text { Kenaikan gaji saya } \\
\text { adalah adil } \\
\text { dibandingkan } \\
\text { dengan kenaikan } \\
\text { gaji rekan kerja di } \\
\text { dalam perusahaan }\end{array}$ & $\begin{array}{lllll}0 & 7 & 30 & 38 & 9\end{array}$ & 3,58 Tinggi \\
\hline $\begin{array}{l}X_{2.5} \text { Gaji saya adil } \\
\text { dibandingkan } \\
\text { dengan apa yang } \\
\text { diterima karyawan } \\
\text { di perusahaan lain } \\
\end{array}$ & $\begin{array}{lllll}0 & 2 & 25 & 40 & 17\end{array}$ & Tinggi \\
\hline $\begin{array}{l}X_{2.6} \text { Tunjangan yang } \\
\text { saya terima adil } \\
\text { dibandingkan } \\
\text { dengan karyawan } \\
\text { di perusahaan lain } \\
\end{array}$ & $\begin{array}{lllll}0 & 1 & 23 & 45 & 15\end{array}$ & 3,88 Tinggi \\
\hline $\begin{array}{c}X_{2.7} \text { Saya merasa diberi } \\
\text { peluang adil dalam } \\
\text { menerima imbalan } \\
\text { insentif } \\
\text { dibandingkan } \\
\text { karyawan di } \\
\text { perusahaan lain } \\
\end{array}$ & $\begin{array}{lllll}0 & 2 & 30 & 37 & 15\end{array}$ & 3,77 Tinggi \\
\hline $\begin{array}{l}X_{2.8} \text { Kenaikan gaji saya } \\
\text { adalah adil } \\
\text { dibandingkan } \\
\text { dengan kenaikan } \\
\text { karyawan di } \\
\text { perusahaan lain } \\
\end{array}$ & $\begin{array}{lllll}0 & 0 & 29 & 35 & 20\end{array}$ & 3,89 Tinggi \\
\hline
\end{tabular}


Tabel 8

Deskripsi Jawaban Responden mengenai Motivasi Kerja

\begin{tabular}{|c|c|c|c|c|}
\hline \multirow{2}{*}{ Indikator } & \multicolumn{2}{|r|}{ Skor } & \multirow{2}{*}{$\begin{array}{r}\text { Rata- } \\
\text { rata }\end{array}$} & \multirow{2}{*}{ Kategori } \\
\hline & 12 & $\begin{array}{lll}3 & 4 & 5\end{array}$ & & \\
\hline $\begin{array}{l}Y_{1.1} \text { Saya mempunyai } \\
\text { hubungan relasi } \\
\text { yang baik dengan } \\
\text { rekan kerja }\end{array}$ & 210 & 173322 & 3,75 & Tinggi \\
\hline $\begin{array}{c}Y_{1.2} \text { Saya taat terhadap } \\
\text { peraturan kerja } \\
\text { dalam perusahaan }\end{array}$ & 23 & 144025 & 3,99 & Tinggi \\
\hline $\begin{array}{l}Y_{1.3} \text { Saya selalu } \\
\text { berusaha } \\
\text { menyelesaikan } \\
\text { pekerjaan sesuai } \\
\text { dengan standard } \\
\text { organisasi } \\
\end{array}$ & $0 \quad 0$ & 194421 & 4,02 & Tinggi \\
\hline $\begin{array}{l}Y_{1.4} \text { Saya selalu } \\
\text { berusaha untuk } \\
\text { tidak melakukan } \\
\text { kesalahan dalam } \\
\text { bekerja } \\
\end{array}$ & $\begin{array}{ll}0 & 9\end{array}$ & $33 \quad 32 \quad 10$ & 3,51 & Tinggi \\
\hline $\begin{array}{c}Y_{1.5} \text { Saya selalu serius } \\
\text { dan berkonsentrasi } \\
\text { dalam bekerja }\end{array}$ & 06 & $\begin{array}{lll}33 & 37 & 8\end{array}$ & 3,56 & Tinggi \\
\hline $\begin{array}{l}Y_{1.6} \text { Saya bekerja } \\
\text { dengan terampil }\end{array}$ & $\begin{array}{ll}0 & 1\end{array}$ & $27 \quad 42 \quad 14$ & 3,82 & Tinggi \\
\hline $\begin{array}{l}Y_{1.7} \text { Saya memiliki } \\
\text { inisiatif untuk } \\
\text { memperbaiki hasil } \\
\text { kerja yang kurang } \\
\text { baik }\end{array}$ & $\begin{array}{ll}0 & 0\end{array}$ & $2541 \quad 18$ & 3,92 & Tinggi \\
\hline $\begin{array}{l}Y_{1.8} \text { Saya selalu bekerja } \\
\text { dengan baik dan } \\
\text { teliti, baik pada } \\
\text { awal bekerja } \\
\text { maupun jam kerja } \\
\text { telah usai } \\
\end{array}$ & $\begin{array}{ll}0 & 1\end{array}$ & 174521 & 4,02 & Tinggi \\
\hline Keselur & & & 3,81 & Tinggi \\
\hline
\end{tabular}

Berdasarkan Tabel 8 dapat dilihat bahwa persepsi tertinggi mengenai motivasi kerja dirasakan oleh karyawan pada indikator kecenderungan untuk selalu bekerja dengan baik dan teliti, baik pada awal bekerja maupun jam kerja telah usai dengan nilai rata-rata sebesar 4,02. Persepsi terendah mengenai motivasi kerja dirasakan oleh karyawan berkaitan dengan adanya usaha dari karyawan untuk tidak melakukan kesalahan dalam bekerja, yaitu dengan ratarata sebesar 3,51. Secara keseluruhan diketahui bahwa rata-rata jawaban responden pada indikator variabel motivasi kerja adalah sebesar 3,81. Hal ini menunjukkan bahwa motivasi kerja dari karyawan PT Indonusa Algaemas Prima Bali dapat dikatakan tinggi.
Tabel 9

Hasil Tabulasi Silang antara Profil dengan Komunikasi Informal

\begin{tabular}{llrrrrrr}
\hline & Profil & \multicolumn{6}{c}{ Komunikasi Informal } \\
\cline { 3 - 8 } & & Rendah & \multicolumn{1}{c}{ Tinggi } & \multicolumn{3}{c}{ Total } \\
\cline { 3 - 8 } & & F & $\%$ & F & $\%$ & \multicolumn{1}{c}{ F } & $\%$ \\
\hline Usia & $<20 \mathrm{Th}$ & 1 & 1,2 & 5 & 6,0 & 6 & 7 \\
& 20-30 Th & 2 & 2,4 & 40 & 47,6 & 42 & 50 \\
& 31-40 Th & 5 & 6,0 & 31 & 36,9 & 36 & 43 \\
Jenis & Laki-laki & 1 & 1,2 & 26 & 31,0 & 27 & 32 \\
Kelamin & Perempuan & 7 & 8,3 & 50 & 59,5 & 57 & 68 \\
Status & Kawin & 5 & 6,0 & 62 & 73,8 & 67 & 80 \\
& Tidak Kawin & 3 & 3,6 & 14 & 16,7 & 17 & 20 \\
Pendidikan & SD & 4 & 4,8 & 48 & 57,1 & 52 & 62 \\
& SMP & 2 & 2,4 & 18 & 21,4 & 20 & 24 \\
& SMA & 1 & 1,2 & 6 & 6,0 & 7 & 7 \\
& SMK & 1 & 1,2 & 4 & 4,8 & 5 & 6 \\
& SPG & 0 & 0 & 1 & 1,2 & 1 & 1 \\
Lama & $<5 \mathrm{Th}$ & 3 & 3,6 & 18 & 21,4 & 21 & 25 \\
Kerja & 5-10 Th & 0 & 0 & 8 & 9,5 & 8 & 10 \\
& 11-20 Th & 5 & 6,0 & 50 & 59,5 & 55 & 65 \\
\hline
\end{tabular}

Dari segi usia diketahui bahwa sebanyak $43 \%$ cenderung memiliki komunikasi informal paling efektif dibanding usia lainnya. Sama halnya dilihat dari segi jenis kelamin perempuan, segi status kawin, segi pendidikan SD, dan segi lama kerja 11-20 tahun juga memiliki persentase yang tinggi. Hal ini karena karyawan lebih mudah menerima dan menyampaikan informasi yang tidak berdasarkan struktur organisasi.

Tabel 10

Hasil Tabulasi Silang antara Profil dengan Gaji

\begin{tabular}{|c|c|c|c|c|c|c|c|}
\hline & \multirow[t]{3}{*}{ Profil } & \multicolumn{6}{|c|}{ Gaji } \\
\hline & & \multicolumn{2}{|c|}{ Rendah } & \multicolumn{2}{|c|}{ Tinggi } & \multicolumn{2}{|c|}{ Total } \\
\hline & & $\mathrm{F}$ & $\%$ & $\mathrm{~F}$ & $\%$ & $F$ & $\%$ \\
\hline \multirow[t]{3}{*}{ Usia } & $<20 \mathrm{Th}$ & 0 & 0 & 6 & 7,1 & 6 & 7 \\
\hline & $20-30 \mathrm{Th}$ & 2 & 2,4 & 40 & 47,6 & 42 & 50 \\
\hline & $31-40 \mathrm{Th}$ & 3 & 3,6 & 33 & 39,3 & 36 & 43 \\
\hline Jenis & Laki-laki & 1 & 1,2 & 26 & 31,0 & 27 & 32 \\
\hline Kelamin & Perempuan & 4 & 4,8 & 53 & 63,1 & 59 & 68 \\
\hline \multirow[t]{2}{*}{ Status } & Kawin & 4 & 4,8 & 63 & 75,0 & 67 & 80 \\
\hline & Tidak Kawin & 1 & 1,2 & 16 & 19,0 & 17 & 20 \\
\hline \multirow[t]{5}{*}{ Pendidikan } & $\mathrm{SD}$ & 1 & 1,2 & 51 & 60,7 & 52 & 62 \\
\hline & SMP & 4 & 4,8 & 16 & 19,0 & 20 & 24 \\
\hline & SMA & 0 & 0 & 6 & 7,1 & 6 & 7 \\
\hline & SMK & 0 & 0 & 5 & 6,0 & 5 & 6 \\
\hline & SPG & 0 & 0 & 1 & 1,2 & 1 & 1 \\
\hline Lama & $<5 \mathrm{Th}$ & 2 & 2,4 & 19 & 22,6 & 21 & 25 \\
\hline \multirow[t]{2}{*}{ Kerja } & 5-10 Th & 1 & 1,2 & 7 & 8,3 & 8 & 10 \\
\hline & $11-20 \mathrm{Th}$ & 2 & 2,4 & 53 & 63,1 & 55 & 65 \\
\hline
\end{tabular}

Dari segi usia dengan rentang 20-30 tahun memiliki persentase tinggi sebanyak 50\%. Karyawan 
cenderung merasa adil dengan gaji yang ada sekarang karena sudah cukup untuk memenuhi kebutuhannya secara wajar. Demikian juga dari segi kelamin wanita, segi status kawin, segi pendidikan SD, dan segi lama kerja 11-20 tahun memiliki persentase paling tinggi.

\section{Tabel 11}

Hasil Tabulasi Silang antara Profil dengan Motivasi Kerja

\begin{tabular}{|c|c|c|c|c|c|c|c|}
\hline & \multirow[t]{3}{*}{ Profil } & \multicolumn{6}{|c|}{ Motivasi Kerja } \\
\hline & & \multicolumn{2}{|c|}{ Rendah } & \multicolumn{2}{|c|}{ Tinggi } & \multicolumn{2}{|c|}{ Total } \\
\hline & & $\mathrm{F}$ & $\%$ & $\mathrm{~F}$ & $\%$ & $\mathrm{~F}$ & $\%$ \\
\hline \multirow[t]{3}{*}{ Usia } & $<20 \mathrm{Th}$ & 1 & 1,2 & 5 & 6,0 & 6 & 7 \\
\hline & $20-30 \mathrm{Th}$ & 4 & 4,8 & 38 & 45,2 & 42 & 50 \\
\hline & $31-40 \mathrm{Th}$ & 3 & 3,6 & 33 & 39,3 & 36 & 43 \\
\hline Jenis & Laki-laki & 2 & 2,4 & 25 & 29,8 & 27 & 32 \\
\hline Kelamin & Perempuan & 6 & 7,1 & 51 & 60,7 & 57 & 68 \\
\hline \multirow[t]{2}{*}{ Status } & Kawin & 6 & 7,1 & 61 & 72,6 & 67 & 80 \\
\hline & Tidak Kawin & 2 & 2,4 & 15 & 17,9 & 17 & 20 \\
\hline \multirow[t]{5}{*}{ Pendidikan } & $\mathrm{SD}$ & 5 & 6,0 & 47 & 56,0 & 52 & 62 \\
\hline & SMP & 3 & 3,6 & 17 & 20,2 & 20 & 24 \\
\hline & SMA & 0 & 0 & 6 & 7,1 & 6 & 7 \\
\hline & SMK & 0 & 0 & 5 & 6,0 & 5 & 6 \\
\hline & SPG & 0 & 0 & 1 & 1,2 & 1 & 1 \\
\hline Lama & $<5 \mathrm{Th}$ & 5 & 6,0 & 16 & 19,0 & 21 & 25 \\
\hline \multirow[t]{2}{*}{ Kerja } & $5-10 \mathrm{Th}$ & 0 & 0 & 8 & 9,5 & 8 & 10 \\
\hline & $11-20 \mathrm{Th}$ & 3 & 3,6 & 52 & 61,9 & 55 & 65 \\
\hline
\end{tabular}

Motivasi kerja karyawan dalam perusahaan termasuk baik bagi karyawan yang berusia 20-30 tahun. Dari segi jenis kelamin, segi status kawin, segi pendidikan SD, dan segi lama kerja 11-20 tahun juga berpengaruh besar bagi perusahaan. Dari hasil analisis regresi linear berganda diperoleh hasil seperti pada Tabel 12.

\section{Tabel 12}

Regresi Linier Berganda

\begin{tabular}{|c|c|c|c|c|}
\hline Model & Koefisien & Beta & $t_{\text {hitung }}$ & Signifikansi \\
\hline (Constant) & 0,066 & & 0,194 & 0,846 \\
\hline $\begin{array}{l}\text { Komunikasi } \\
\text { Informal }\end{array}$ & 0,412 & 0,461 & 6,072 & 0,000 \\
\hline Gaji & 0,560 & 0,470 & 6,181 & 0,000 \\
\hline$R$ & & $=0,781$ & & \\
\hline$R^{2}$ & & $=0,610$ & & \\
\hline$F_{\text {hitung }}$ & & $=63,458$ & & \\
\hline Sig. $F$ & & $=0,000$ & & \\
\hline
\end{tabular}

Model regresi linier berganda dalam penelitian ini adalah $Y=0,066+0,412 X_{1}+0,560 X_{2}$

Berdasarkan Tabel 12 dapat diketahui bahwa varibel komunikasi informal $\left(X_{I}\right)$ dan gaji $\left(X_{2}\right)$ memiliki pengaruh positif terhadap motivasi kerja karyawan (Y). Nilai koefisien regresi variabel komunikasi informal $\left(X_{I}\right)$ adalah sebesar 0,412 , artinya jika $X_{I}$ berubah satu satuan, maka $Y$ akan berubah sebesar 0,412 dengan anggapan variabel $X_{2}$ tetap. Nilai koefisien regresi variabel gaji $\left(X_{2}\right)$ adalah sebesar 0,560, artinya jika $X_{2}$ berubah satu satuan, maka $Y$ akan berubah sebesar 0,560 dengan anggapan variabel $X_{I}$ tetap. Koefisien korelasi $(R)$ sebesar 0,781 menunjukkan bahwa hubungan antara variabel-variabel bebas yaitu komunikasi informal $\left(X_{I}\right)$ dan gaji $\left(X_{2}\right)$ terhadap motivasi kerja $(Y)$ di PT Indonusa Algaemas Prima Bali adalah tergolong kuat. Koefisien determinasi $\left(R^{2}\right)$ yang diperoleh adalah sebesar 0,610 , memiliki arti bahwa motivasi kerja dari karyawan PT Indonusa Algaemas Prima Bali dapat dipengaruhi oleh faktor komunikasi informal dan gaji yaitu sebesar $61 \%$, sedangkan 39\% sisanya dipengaruhi oleh faktor lain yang tidak digunakan dalam penelitian ini.

Tabel hasil analisis regresi linier berganda juga menunjukkan bahwa kedua variabel bebas yaitu komunikasi informal dan gaji masing-masing memiliki nilai signifikansi uji $t$ di bawah $0,05(\alpha=5 \%)$. Dengan demikian dapat disimpulkan bahwa secara parsial, masing-masing variabel tersebut memiliki pengaruh yang signifikan terhadap motivasi kerja dari karyawan PT Indonusa Algaemas Prima Bali. Uji kebaikan model $F$ memiliki daya estimasi sebab nilai $F$ signifikan pada $1 \%$, sehingga dapat disimpulkan bahwa variabel bebas penelitian yaitu komunikasi informal dan gaji (uji model) berpengaruh signifikan terhadap motivasi kerja dari karyawan PT Indonusa Algaemas Prima Bali. Hal ini berarti hipotesis penelitian dapat diterima.

Hasil penelitian ini sejalan dengan penelitian terdahulu. Menurut Wahyuningsih et al. (2012) dengan nilai $t_{\text {hitung }}$ 6,693 menunjukkan bahwa komunikasi berpengaruh positif dan signifikan terhadap motivasi kerja karyawan Badan Kekaryawanan Daerah Kota Surakarta. Komunikasi antara pimpinan dan karyawan dapat berupa arahan yang diberikan pimpinan untuk mengatasi masalah pekerjaan yang terjadi di tempat kerja. Pimpinan juga bisa bersikap terbuka dalam pelaksanaan komunikasi sehingga karyawan merasa diperhatikan oleh perusahaan dan kerjasama yang baik dapat terwujud.

Penelitian Nugraha et al. (2013) menyatakan ada pengaruh signifikan antara insentif finansial (termasuk gaji) terhadap motivasi kerja. Insentif finansial secara langsung mempengaruhi motivasi sebesar $6,91 \%$. Sama halnya dengan hasil pengamatan dan wawancara yang dilakukan oleh Sumbangsih dan Nelisa (2013) yang menyimpulkan bahwa pemberian insentif yang digunakan oleh pihak Perpustakaan Universitas Bung Hatta Padang kepada pustakawan adalah insentif yang umumnya bersifat uang. Karya- 
wan diharapkan mampu mempunyai motivasi kerja yang nantinya akan menguntungkan perpustakaan. Hal tersebut diantaranya mampu meningkatkan produktivitas pustakawan dan karyawan, meningkatkan kedisiplinan pustakawan dan karyawan, meningkatkan loyalitas, kreativitas, dan partisipasi pustakawan dan karyawan, serta meningkatkan tanggung jawab dan loyalitas pustakawan dan karyawan. Penelitian Wijayanti dan Yuniari (2013) menyatakan bahwa variabel insentif finansial merupakan variabel yang mempunyai pengaruh dominan terhadap semangat kerja karyawan Meranggi Jati Garment dengan nilai standardized coefficient beta absolut tertinggi yaitu 0,476

\section{Simpulan dan Implikasi}

Berdasarkan hasil penelitian, dapat diketahui bahwa komunikasi informal $\left(X_{I}\right)$ telah terbukti sebagai faktor berpengaruh terhadap motivasi kerja karyawan. Hal ini dapat dibuktikan dengan hasil analisis regresi linier berganda yang menunjukkan varibel komunikasi informal $\left(X_{I}\right)$ berpengaruh positif terhadap motivasi kerja karyawan. Komunikasi informal digunakan untuk memperlancar pekerjaan. Dalam hal ini termasuk hubungan antara pemimpin dan bawahannya. Perintah yang diberikan juga bisa tidak sesuai struktur organisasi. Pemimpin bisa meminta karyawan lain untuk memberitakan perintahnya kepada orang yang dimaksud. Komunikasi informal lebih terlihat tidak canggung dan penyampaiannya dan lebih bisa diterima.

Hasil penelitian ini juga menyebutkan bahwa gaji $\left(X_{2}\right)$ telah terbukti sebagai faktor yang paling berpengaruh terhadap motivasi kerja karyawan di perusahaan. Ini dibuktikan dengan hasil analisis linier berganda bahwa gaji $\left(X_{2}\right)$ memiliki pengaruh positif dan signifikan terhadap motivasi kerja. Gaji memberikan dampak besar bagi kehidupan karyawan. Karyawan akan bisa bertahan dengan gaji yang sesuai dengan pekerjaan yang dilakukan.

\section{Daftar Referensi}

Adiwinata, I. \& Sutanto E. M. (2014). Pengaruh kepuasan kerja dan motivasi kerja terhadap produktivitas kerja karyawan CV Intaf Lumajang. Agora, 2(1).

Arep, I. \& Tanjung, H. (2005). Manajemen motivasi. Jakarta: Grasindo.
Cooper, D. R. \& Schindler, P. S. (2008). Business research methods. $10^{\text {th }}$ Ed. New York: McGrawHill.

Disposoedarmo. (2008). Komunikasi penugasan. Jakarta: PT Toko Gunung Agung.

Ertanto, Y. D. \& Suharnomo. (2011). Pengaruh gaji terhadap kinerja karyawan dengan self esteem sebagai variabel intervening. Undergraduate Thesis. Jurnal Universitas Diponegoro.

George, J. M. \& Jones, G. R. (2005). Understanding and managing organizational behaviour. $4^{\text {th }} \mathrm{Ed}$. New Jersey: Upper Saddle River.

Kreitner, R. \& Kinicki, A. (2005). Perilaku organisasi. Jakarta: Salemba Empat.

Mangkunegara, A. P. (2007). Manajemen sumber day a manusia. Jakarta: Salemba Empat.

Nugraha, G., Astuti, E. S., \& Hakam, M. S. (2013). Pengaruh insentif finansial dan insentif non finansial terhadap motivasi dan semangat kerja karyawan (studi pada karyawan PT Bank Negara Indonesia Persero Tbk. kantor cabang utama Madura). Jurnal Administrasi Bisnis, 6(2), 1-8.

Putra, T. U. (2013). Pengaruh komunikasi pimpinan terhadap motivasi kerja di kabag humas DPRD provinsi Kalimantan Timur. Ejournal Ilmu Komunikasi, 1(2), 294-259.

Sugiyono. (2010). Statistika untuk penelitian. Bandung: Alfabeta.

Sumbangsih, N. \& Nelisa, M. (2013). Pengaruh pemberian insentif terhadap motivasi kerja pustakawan di perpustakaan Universtias Bung Hatta. Jurnal Ilmu Informasi Perpustakaan dan Kearsipan, 2(1), Seri C, 178-185.

Wahyuningsih, S., Binarsih S. R., \& Istiatin. (2012). Pengaruh kepemimpinan, disiplin kerja dan komunikasi terhadap motivasi kerja karyawan badan kekaryawanan daerah Kota Surakarta. $M a-$ najemen Bisnis Syariah, 2(7), Agustus 2012.

Wijayanti, C. I. A. \& Yuniari, M. (2013). Pengaruh insentif finansial, motivasi non finansial dan lingkungan kerja fisik terhadap semangat kerja karyawan. E-Jurnal Manajemen Universitas Udayana, 2(3), 369-382.

Winarni \& Utomo, H. (2013). Pengaruh gaji terhadap kinerja karyawan kantor perpustakaan dan arsip Kota Salatiga melalui variabel motivasi kerja sebagai variabel intervening. Among Makarti, 6 (11), 48-71. 